\title{
STRESS EFFECT FACTORS AND SOCIO-PATHOLOGICAL PHENOMENA IN TEACHING AND LEARNING ENVIRONMENT
}

\author{
Radka Vaníčková ${ }^{1}$ \\ Jana Hanuliaková ${ }^{2}$ \\ Dáša Porubčanová ${ }^{3}$
}

Received: June 10, 2019 / Revised: July 25, 2019/ Accepted: October 17, 2019

(C) Association of Economists and Managers of the Balkans, 2019

\begin{abstract}
Stress represents an inner human state in a positive or negative sense that can be considered a threat. From the researchers conducted in the Czech and Slovak Republic, it can be shown that adequate stress has a significant effect on brain activity. Stress in teaching and learning environment leads to the emergence and development of socio-pathological phenomena. Contributors focus on social, emotional and behaviour stress factors in pupils/students with an impact on the occurrence of socio-pathological phenomena and risk behaviours in the educational process. The main methods of realization of the empirical research were the questionnaire survey, the own structure of the contribution authors, the experiment method, the statistical method of the F-test of equivalence and the t-test with uneven dispersion. The authors of the paper further analysed the statements of teachers who reported the most frequent preferences of stress factors in students.
\end{abstract}

Keywords: Stress factors, social-pathological phenomena, educational process, stressors of high school student, student's soft-skills.

\section{JEL Classification I25}

This paper was presented at the Fifth International Scientific Conference on Knowledge Based Sustainable Development - ERAZ 2019 - May 23, Budapest, Hungary, www.eraz.org.rs

Radka Vaníčková

vanickovaradka@gmail.com 


\section{INTRODUCTION}

The aim of this contribution is to identify and classify stress effect factors and stress situations of high school that are involved in formation of socio-pathological phenomena. Within the framework of experimental group have eliminated stress factors and evaluated to reduce the impact and dangerous consequences in behaviour, value orientation and adolescent attitudes.

In the theoretical-methodological part of the contribution are defined stress factors, stress situations, socio-pathological phenomena and teaching and learning environment.

In the analytic part of the contribution is focused on finding a statistical dependence on the presence of stress in teaching and learning environment, the behaviour of pupils the presence and stress effect factors in the educational process.

\section{LITERATURE REVIEW}

Scientific research of stress in various environments and connections dates back to the end of 1950's. Research of the stress was done by (Berg and Cornell, 2016), who were focusing on the job stress; manager's stress of teacher's profession and of teachers; strategies of coping with stress. Authors (Blašková, Blaško, Figurská and Sokol, 2015) concentrated on coping oriented on problem emotions and strategies. Next authors such as (Braun and Carlotto, 2014) dealt with the perception of stress situation by university students in Slovakia at the secondary school students. According to (Cefai and Camilleri, 2015) the research concentrated on diagnosis of factors of stress of adolescents at the age of 15 - 16. In the sample of 1648 students, he found out that adolescents are mostly threatened by psychical stress that was most commonly associated with examining, testing during classes or passing final examinations (Cordella and Pojani, 2014).

Cognitive strategies of success and stress factors (from disadvantaged family environment) were subjects of more important studies and researches and also programs in the USA in 1990's (see GED program PERRY intervention to school success of children from low-stimulating environment already in an early age). Many similar studies were dedicated to factors of coping and success (da Silva, Bolsoni, Rodriguess, Capellini et al., 2015) while they secondarily indicated stress as the factor of failure. The significant sample (75 students), how to say (Davies, Olson, Meyer, Renner et al., 2016) was monitored in the context of stress demonstrations in the sphere of transition of students to higher grade of education. The research of stress of students at the age of $10-11$ who are making transition to higher grade of education was done in London by team of experts from Karagiannopoulou. Students from families that were categorically classified as coherent and adaptable have experienced stress resulting from transition to higher degree only exceptionally (Denscombe, 2000). On the contrary students from families characterized as unbalanced (chaotic, rigid) were experiencing stress more often even in the second period of school year (Eldor, 2018). Murberg's research took place in Norway, 535 high school students at the age of 13 - 16 went through the research. On the basis of his extensive study he grouped the stress in areas to discover everyday stress present in the common activity in the class (Eva and Thayer, 2017) and (Fisher, 2011). By means of questionnaire and consecutive interview with 50 elementary school students at the age of 8 - 9 in England and Greece they gathered information that students link the everyday stress to teacher's rebuke of undisciplined student, teacher's feedback on student's work with many errors and too student's inability to answer teacher's questions. The participants were 384 Greek primary schoolteachers, aged 25 to 59 years old (mean age $=41$ years and 4 months), 146 males $(38 \%)$ and 238 females $(62 \%)$. They completed the Questionnaire on Teacher Stress and 
the Maslach Burnout Inventory - Educators Survey - MBI-ES. It was found that Greek primary schoolteachers report low levels of stress and that their stress is predicted by burnout and teaching students with special educational needs mention (Folkman and Lazarus, 1980) and (Gabrhelová, 2017). Reviewing a selection of the literature published after (Gaillior and Baumeister, 2007) seminal review on the impact to stress on close relationships this review conceptualizes to associations between different types of stressors - particularly those that originate outside (external) and inside (internal) relationship but relationship satisfaction within romantic too. The stressor is the situation to which the individual is being exposed and in order to face it, he has to adapt by (Ganzel, Morris and Wethington, 2010).

Mention division of stressors in those primaries, i.e. those that affect organism directly and those secondary that bring obstacles during the activity. The influence of stress on the person does not need to have only negative character. Universities form the intellectual level and motivation of all individuals and groups in the country; speak authors (Gouda, Luong, Schmidt and Bauer, 2016). Consequences of student's stress are reflected in every component of student's personality; inform (Grise-Owens, Miller, Escobar Ratliff and George, 2018). It is reflected mostly on human's health, comments (Gustems, Carnicer, Calderón and Calderón Garrido, 2019). The most common symptoms of student's stress that can be perceived by teacher are fatigue, exhaustion, headache, problems with stomach, signs of depression, change of dietary habits and weight loss (Havelka, Kropáč, Serafin, Chráska et al., 2015). Behavioural symptoms are represented by addictions, smoking, abnormal workout, and irrationality loosing nerves", inabilities to concentrate, inability to complete a task, mention (Hong, 2012).

Stress is closely related to the way of life that student leads, expresses (Hutkemri Ahmad and Jelas, 2017). When student experiences long-term inadequate big stress and he is not able to copy with it, it can be associated with smoking, excessive consumption of alcohol, lack of exercise etc. Research done by Mederi and coll. proves that $61 \%$ of secondary school students consider school environment as an environment that stresses them, what is a high occurrence compared to other types of environment ( $20.36 \%$ none, $11.13 \%$ family, $7.23 \%$ outside of family and school, $1 \%$ not indicated), say (Inmaculada and Glòria, 2016). On 10283 addressed respondents the authors have investigated determinants that have negative influence on well-being of high school students, adds (Kalyva, 2013). It resulted from the realized research that students with a bad well-being smoke regularly, they drink coffee and beer almost daily, they take medicine for stimulation and calming down, they have already took drugs, or they take drugs regularly, they miss confidential person when solving problems and relationships, think (Kandlhofer and Steinbauer, 2016) and (Kopp, Kuhlmann and Golpelwar, 2016), they have suicidal tendencies or they have already tried to commit a suicide, they have already had sexual intercourse and they now have a sexual life. For this period indicate the following possible stress factors: continuing with education (Lai and Kwan, 2017), leaving parents' house, intimate relationships with the opposite sex, conclusion of the marriage, planning of the family, birth of children, professional growth, and unemployment. Significant factors that are stressing for students are presented in didactical-methodical work of the teacher (form of communication, methods, and way of evaluation, problem solving and educational climate), say (Lawner and Bradbury, 2017).

The relation between school climate and resilience of students is confirmed by the research authors (Leach, Nygaard, Chipman, Brunsvold et al., 2019) and (Lin and Huang, 2014). The authors found out that there is a relation between the level of resilience of students and their perception of school climate. 


\section{MATERIAL AND METHODS}

We have differentiated investigation of stress and socio-pathological phenomena into three fields: within the first part we were investigating and making diagnose of high school student's stress factors and determinants, in the second part we made a long-term experimental research in selected research universe and third part in intentions of recommendations for pedagogical practice we have focused on programs of elimination of stress from the point of view of teacher's support of student when dealing with social-emotional symptoms. Main methods for realization of empirical investigation were the questionnaire of the own construction, method of experiment, statistical method F-test for equality of variances and t-test with unequal variance. By the F-test, we decide whether the experimental intervention has an influence on the variability (scattering s2) of the random variable under investigation. We test the zero hypotheses in the F-test: $\mathrm{H}_{0}: \mathrm{s}_{1}{ }^{2}=\mathrm{s}_{2}{ }^{2}$ and compare with the critical value:

If $\mathrm{F}>$ Fkrit. $=>$ reject the zero hypotheses $\mathrm{H}_{0}: \mathrm{s}_{1}{ }^{2}=\mathrm{s}_{2}{ }^{2}$. The scattering of both files differs statistically significantly, i.e. the selections come from two different basic sets with different variations of $\mathrm{s}_{1}^{2}$ and $\mathrm{s}_{2}^{2},(\mathrm{p}<0.05$ (or $\mathrm{p}<0.01$ according to the chosen significance level a)).

If $\mathrm{F}<$ Fkrit. $=>$ We cannot reject the hypothesis $\mathrm{H}_{0}$. The scattering of both sets is not statistically significantly different, i.e. the selections come from the same basic set with a common scattering $\left.\mathrm{s}_{2}\right),(\mathrm{p}>0.05)$. The objective of the F-test on the Equivalence of Two Scatters is to verify whether the sample sets originate from the distribution with the same scatter, i.e. whether the files show approximately the same dispersion of the observed random variable.

The objective of the contribution was to identify and classify stressors, stress situations of high school that are involved in formation of socio-pathological phenomena. Within the framework of experimental group have eliminated stress factors and evaluated to reduce the impact and dangerous consequences in behaviour, value orientation and adolescent attitudes.

\section{RESULTS AND DISCUSSION}

\subsection{Stressors of High School Students}

We were finding out stressors and starters of stress at high school students through questionnaire method with open items. By analysing statements of respondents $(\mathrm{N}=298)$ we have processed proportional overview of most frequently mentioned stressors oral and written testing $(26.47 \%)$, bullying $(17.05 \%)$, teacher $(16.60 \%)$, bad grades $(8.83 \%)$, inability to integrate $(7.47 \%)$, expectations of parents $(5.48 \%)$, weak family social background $(4.87 \%)$, student's failure $(4.41 \%)$, not managing schoolwork (4.57\%), disinterest in study (4.26\%). When making qualitative analysis of all gathered data it is possible to segment stated items of respondents into more fields of stressors of student, e.g. examining of students $(20.67 \%)$, results of learning of students (19.6\%), personality of teacher (17.81\%), social-pathological phenomenon's (16.15\%), social relationships in class $(13.18 \%)$, personality of student $(12.59 \%)$.

We have processed framework groups on the basis of number of their occurrence. A most source of stress is considered examining and testing of knowledge of students. Manner in which teacher verifies knowledge and teacher's skills are evaluated as stressful. A significant number of teachers stated that students are stressed by oral testing, performing in front of all group of students, project presentation. The important factor of education is teacher and his methodical-didactical 
approach. Teacher's influencing of student is a broad scale activity, etc. motivation manner, quality of pedagogical communication, say (Meriläinen, 2014), level of interactions, form and manner of mediation of housework, possibility of knowledge testing, evaluation manner, approach to student, respecting principles etc. In our work we indicate evaluation of teacher as a potential source of stress for student are for examples ridiculing and humiliating $(19.17 \%)$, strict behaviour (13.15 $\%)$, high demands on student (12.33\%), nun objective evaluation (10.68\%), behaviour - stressed, moody, not calm $(9.32 \%)$, picking on a student (8.77\%), cries, insults, vulgarisms (8.22\%), teacher's dominance (6.85\%), disregard (6.30\%), excessive testing $(5.21 \%)$.

In the view of stress experienced in school conditions we have to make appeal to the fact that in many cases it can develop into socio-pathological phenomena and improper manifestation of behaviour, inform (Özberk, Dağli, Altinay and Altinay, 2017). Secondary school students most frequently experience bullying, aggressive behaviour, alcohol, smoking, drugs, contemporary phenomenon of bullying and cyber-bullying, add (Prilleltensky, Neff and Bessell, 2016). Important part of quality of student's life at school is positive experiencing of interactions in class on the level teacher-student, student-student and student-group. Student's social competences must be appreciated in every activity within the framework of education as well as during events organised by school, agree (Randall and Bodenmann, 2017). The most stressful for high school students is their inability to become integrated in group. From the point of view of student's personality stressors are failure, disinterest in studies, schoolwork and weak social family environment, think (Reichl, Wach, Spinath Brünken and Karbach, 2014).

\subsection{Stress Effect Factors and Social-Pathological Phenomena in Teaching and Learning Environment}

The second part of the research was focused on finding a statistical dependence on the presence of stress in teaching and learning environment and the occurrence of socio-pathological phenomena, and whether the behaviour of pupils with socio-pathological manifestations has been reinforced by the presence and stress effect factors in the educational process.

The analysis was performed by standard statistic methods, expressing the significance of the difference between the obtained numerical data representing the variables entering the relations. To a successful and relevant course of the experiment, two almost identical groups of pupils from secondary schools from the Slovak Republic were chosen and monitored throughout the school year. It is difficult to create a purely random sample. For that reason, we worked with completed classes of boys of the same age and similar level. Sample selection was focused on comparability of relevant features relevant to the research, i.e. the same conditions for both groups in terms of material security and also in terms of the skills and expertise of teachers who were of the same age and gender, and who worked by different methods during the experiment. Pupils of the sample attended the same secondary school, the same year and completed the same curriculum with the same hour duration. Verification of specified hypotheses was performed by a special experimental plan.

The processing, evaluation and analysis of the data obtained was processed using standard methods of mathematical statistics to determine the impact of school stress and the incidence of socio-pathological phenomena in teaching and learning environment. To verify the level of stress factors on the sample of pupils involved in the experiment, we used a questionnaire to determine the extent of stress factors on pupils. According to (Roslan, Sharifach and Thirumalai, 2012) the rate of representation of pathological phenomena was determined by a pedagogical experiment in 
which the control group provided educational conditions without the influence of stress factors; they were exposed to a minimal extent. The experimental group was subjected to stress factors during contact education.

H1 hypothesis stated: Pupils exposed to stress factors in teaching and learning environment do not achieve a lower incidence of socio-pathological phenomena compared to pupils in teaching and learning environment of contact education without stress activity. To verify the assumed hypothesis, assuming that the distribution of the samples is approximately normal, we used statistical methods: F-test for equality of variances that would assess the difference between the variances. Variable $\mathrm{F}=\sigma_{1}{ }^{2} / \sigma_{2}{ }^{2}$ was the test criterion. Its comparison with the critical value at the significance level of $\alpha=0.05$ would define and assess the results. Further, a sample t-test was used with inequality of variance at the significance levels of $\alpha=0.05$ and $\alpha=0.01$. To verify the values, non-parametric Wilcoxon test (Mann - Whitney U-test) was used.

Table 1. Results of empirical research Source: Authors.

\begin{tabular}{|c|c|c|}
\hline Pupil's number & $\begin{array}{l}\text { Group without } \\
\text { stress factors }\end{array}$ & $\begin{array}{l}\text { Group with } \\
\text { stress factors }\end{array}$ \\
\hline 1 & 49 & 48 \\
\hline 2 & 36 & 49 \\
\hline 3 & 39 & 38 \\
\hline 4 & 49 & 32 \\
\hline 5 & 43 & 35 \\
\hline 6 & 37 & 36 \\
\hline 7 & 39 & 39 \\
\hline 8 & 5 & 41 \\
\hline 9 & 28 & 29 \\
\hline 10 & 48 & 48 \\
\hline 11 & 35 & 47 \\
\hline 12 & 45 & 36 \\
\hline 13 & 29 & 29 \\
\hline 14 & 41 & 39 \\
\hline 15 & 34 & 45 \\
\hline 16 & 3 & 46 \\
\hline 17 & 33 & 47 \\
\hline 18 & 42 & 39 \\
\hline 19 & 12 & 50 \\
\hline 20 & 34 & 35 \\
\hline 21 & 29 & 26 \\
\hline 22 & 31 & 39 \\
\hline 23 & 33 & 40 \\
\hline 24 & 24 & 36 \\
\hline 25 & 42 & 43 \\
\hline 26 & 41 & 44 \\
\hline 27 & 43 & 32 \\
\hline 28 & 47 & 46 \\
\hline
\end{tabular}




\begin{tabular}{|c|c|c|}
\hline Pupil's number & $\begin{array}{l}\text { Group without } \\
\text { stress factors }\end{array}$ & $\begin{array}{c}\text { Group with } \\
\text { stress factors }\end{array}$ \\
\hline 29 & 34 & 45 \\
\hline 30 & 35 & 47 \\
\hline 31 & 26 & 35 \\
\hline 32 & 36 & 36 \\
\hline 33 & 50 & 8 \\
\hline 34 & 41 & 37 \\
\hline 35 & 38 & 32 \\
\hline 36 & 40 & 45 \\
\hline 37 & 24 & 48 \\
\hline 38 & 29 & 49 \\
\hline 39 & 34 & 46 \\
\hline 40 & 42 & 38 \\
\hline 41 & 29 & 39 \\
\hline 42 & 31 & 36 \\
\hline 43 & 32 & 32 \\
\hline 44 & 26 & 35 \\
\hline 45 & 29 & 34 \\
\hline 46 & 34 & 49 \\
\hline 47 & 27 & 40 \\
\hline 48 & 41 & 21 \\
\hline 49 & 35 & 35 \\
\hline 50 & 36 & 38 \\
\hline 51 & 40 & 37 \\
\hline 52 & 42 & 39 \\
\hline 53 & 24 & 42 \\
\hline 54 & 18 & 46 \\
\hline 55 & 43 & 45 \\
\hline 56 & 37 & 37 \\
\hline 57 & 34 & 36 \\
\hline 58 & 32 & 39 \\
\hline 59 & 29 & 46 \\
\hline 60 & 40 & 44 \\
\hline 61 & 36 & 43 \\
\hline 62 & 35 & 50 \\
\hline 63 & 27 & 47 \\
\hline 64 & 42 & 48 \\
\hline 65 & 38 & 41 \\
\hline 66 & 36 & 39 \\
\hline 67 & 39 & 40 \\
\hline 68 & 25 & 38 \\
\hline 69 & 32 & 34 \\
\hline 70 & 21 & 35 \\
\hline 71 & 41 & 32 \\
\hline
\end{tabular}


Table 1 shows the results obtained from the research survey for both groups of pupils, one group of pupils being exposed to a stress factors in teaching and learning environment, while the other group was not, or the effects of stressors were minimized. F-test for equality of variances found a difference between the parameter variations. Tested value was $\mathrm{F}=\sigma_{1}{ }^{2} / \sigma_{2}{ }^{2}$, compared to the critical value at the significance level of $\alpha=0.05$, entered into MS Excel, reported the statistics as described in table 2. Value of tested criterion was calculated $\mathrm{F}=1.557437553$, while the critical value $\mathrm{F}_{\text {crit. }}=1.485688974$, meaning. $\mathrm{F}>\mathrm{F}_{\text {crit }}$, as predicted. Since the calculated $\mathrm{F}$ value is greater than the critical value, the difference between variances is considered to be statistically significant and therefore, for the comparison of the mean values, we have chosen a two-sample t-test with variance inequality.

Table 2. Statistics of the two-sample F-test at the level of significance $\alpha=0.05$.

Source: Authors.

\begin{tabular}{|l|c|c|}
\hline $\begin{array}{l}\text { Two-sample } \\
\text { F-test of the variance }\end{array}$ & Sample 1 & Sample 2 \\
\hline Mean value & 34.23943662 & 39.3943662 \\
\hline Variance & 82.69899396 & 53.09939638 \\
\hline Observation & 71 & 71 \\
\hline Difference & 70 & 70 \\
\hline F & 1.557437553 & \\
\hline $\mathrm{P}(\mathrm{F}<=\mathrm{f})(1)$ & 0.032933546 & \\
\hline F crit $(1)$ & 1.485688974 & \\
\hline
\end{tabular}

Sample t-test with inequality of variance at two significance level $\alpha=0.05$ and $\alpha=0.01$; Basic characteristics of the sample were calculated using MS Excel at the significance level of $\alpha=0.05$ - see Table 3.

Table 3. Statistics of the two-sample t-test with inequality of variance by Excel at the significance level of $\alpha=0.05$. Source: Authors.

\begin{tabular}{|l|c|c|}
\hline $\begin{array}{l}\text { Two-sample t-test with } \\
\text { inequality of variance }\end{array}$ & Sample 1 & Sample 2 \\
\hline Mean value & 34.23943662 & 39.3943662 \\
\hline Variance & 82.69899396 & 53.09939638 \\
\hline Observation & 71 & 71 \\
\hline Difference of mean values & 0 & \\
\hline Difference & 134 & \\
\hline $\mathrm{t}$ stat & -3.727387976 & \\
\hline $\mathrm{P}(\mathrm{T}<=\mathrm{t})(1)$ & 0.000142192 & \\
\hline $\mathrm{t}$ crit $(1)$ & 1.656304542 & \\
\hline $\mathrm{P}(\mathrm{T}<=\mathrm{t})(2)$ & 0.000284383 & \\
\hline $\mathrm{t}$ crit $(2)$ & 1.97782573 & \\
\hline
\end{tabular}

Test value was calculated as $t=-3.727387976$ by comparing this value with the critical values of the two-sample $\mathrm{t}$-test $\mathrm{t}_{\text {crit1 }} .=1.656304542$ and $\mathrm{t}_{\text {crit2. }}=1.97782573$ revealed that $|\mathrm{t}|>\mathrm{t}_{\text {crit }}$, meaning that the mean number of points of both samples are not equal at the level of significance of $\alpha=0.05$. 
Table 4. Statistics of the two-sample t-test with inequality of variance at the level of significance of $\alpha=0.01$. Source: Authors.

\begin{tabular}{|l|c|c|}
\hline $\begin{array}{l}\text { Two-sample t-test with } \\
\text { inequality of variance }\end{array}$ & Sample 1 & Sample 2 \\
\hline Mean value & 34.23943662 & 39.3943662 \\
\hline Variance & 82.69899396 & 53.09939638 \\
\hline Observation & 71 & 71 \\
\hline Difference of mean values & 0 & \\
\hline Difference & 134 & \\
\hline $\mathrm{t}$ stat & -3.727387976 & \\
\hline $\mathrm{P}(\mathrm{T}<=\mathrm{t})(1)$ & 0.000142192 & \\
\hline $\mathrm{t}$ crit $(1)$ & 2.354498123 & \\
\hline $\mathrm{P}(\mathrm{T}<=\mathrm{t})(2)$ & 0.000284383 & \\
\hline $\mathrm{t}$ crit $(2)$ & 2.613017054 & \\
\hline
\end{tabular}

Test value was calculated as $\mathrm{t}=-3.727387976$. By comparing this value with the critical values of the two-sample $\mathrm{t}_{\text {critl }}=2.354498123$ and $\mathrm{t}_{\text {crit2. }}=2.613017054$ revealed that $|\mathrm{t}|>\mathrm{t}_{\text {krit }}$, meaning that the mean number of points of both samples are not equal at the level of significance of $\alpha=0.01$. To verify the hypothesis at the level of significance of $\alpha=0.05$ and $\alpha=0.01$ Wilcoxon test (Mann - Whitney U-test) was used, see Table 5.

Table 5. Statistics of Wilcoxon test (Mann - Whitney U-test). Source: Authors.

\begin{tabular}{|c|c|c|c|c|c|c|c|}
\hline Experiment & $\begin{array}{c}\text { Obtained } \\
\text { points }\end{array}$ & $\begin{array}{c}\text { Order for } \\
\text { calculation }\end{array}$ & $\begin{array}{c}\text { Auxiliary } \\
\text { field }\end{array}$ & Experiment & $\begin{array}{c}\text { Obtained } \\
\text { points }\end{array}$ & $\begin{array}{c}\text { Order for } \\
\text { calculation }\end{array}$ & $\begin{array}{c}\text { Auxiliary } \\
\text { field }\end{array}$ \\
\hline aa & 3 & 1 & 1 & A & 38 & 74.5 & 73 \\
\hline aa & 5 & 2 & 2 & B & 38 & 74.5 & 74 \\
\hline bb & 8 & 3 & 3 & B & 38 & 74.5 & 75 \\
\hline aa & 12 & 4 & 4 & B & 38 & 74.5 & 76 \\
\hline aa & 18 & 5 & 5 & B & 38 & 74.5 & 77 \\
\hline aa & 21 & 6.5 & 6 & a & 39 & 85 & 78 \\
\hline bb & 21 & 6.5 & 7 & a & 39 & 85 & 79 \\
\hline aa & 24 & 9 & 8 & a & 39 & 85 & 80 \\
\hline aa & 24 & 9 & 9 & b & 39 & 85 & 81 \\
\hline aa & 24 & 9 & 10 & b & 39 & 85 & 82 \\
\hline aa & 25 & 11 & 11 & b & 39 & 85 & 83 \\
\hline aa & 26 & 13 & 12 & b & 39 & 85 & 84 \\
\hline aa & 26 & 13 & 13 & b & 39 & 85 & 85 \\
\hline bb & 26 & 13 & 14 & b & 39 & 85 & 86 \\
\hline aa & 27 & 15.5 & 15 & b & 39 & 85 & 87 \\
\hline aa & 27 & 15.5 & 16 & b & 39 & 85 & 88 \\
\hline aa & 28 & 17 & 17 & a & 40 & 91.5 & 89 \\
\hline aa & 29 & 21.5 & 18 & a & 40 & 91.5 & 90 \\
\hline aa & 29 & 21.5 & 19 & a & 40 & 91.5 & 91 \\
\hline aa & 29 & 21.5 & 20 & b & 40 & 91.5 & 92 \\
\hline aa & 29 & 21.5 & 21 & b & 40 & 91.5 & 93 \\
\hline aa & 29 & 21.5 & 22 & b & 40 & 91.5 & 94 \\
\hline aa & 29 & 21.5 & 23 & a & 41 & 98 & 95 \\
\hline & & & & & & & \\
\hline
\end{tabular}


Balkan JETSS (2019) 2: 169-184

\begin{tabular}{|c|c|c|c|c|c|c|c|}
\hline Experiment & $\begin{array}{c}\text { Obtained } \\
\text { points }\end{array}$ & $\begin{array}{c}\text { Order for } \\
\text { calculation }\end{array}$ & $\begin{array}{l}\text { Auxiliary } \\
\text { field }\end{array}$ & Experiment & $\begin{array}{c}\text { Obtained } \\
\text { points }\end{array}$ & $\begin{array}{c}\text { Order for } \\
\text { calculation }\end{array}$ & $\begin{array}{c}\text { Auxiliary } \\
\text { field }\end{array}$ \\
\hline $\mathrm{bb}$ & 29 & 21.5 & 24 & $\mathrm{a}$ & 41 & 98 & 96 \\
\hline $\mathrm{bb}$ & 29 & 21.5 & 25 & $a$ & 41 & 98 & 97 \\
\hline aa & 31 & 26.5 & 26 & $\mathrm{a}$ & 41 & 98 & 98 \\
\hline aa & 31 & 26.5 & 27 & $\mathrm{a}$ & 41 & 98 & 99 \\
\hline aa & 32 & 31.5 & 28 & $\mathrm{~b}$ & 41 & 98 & 100 \\
\hline aa & 32 & 31.5 & 29 & $b$ & 41 & 98 & 101 \\
\hline aa & 32 & 31.5 & 30 & $\mathrm{a}$ & 42 & 104.5 & 102 \\
\hline $\mathrm{bb}$ & 32 & 31.5 & 31 & $\mathrm{a}$ & 42 & 104.5 & 103 \\
\hline $\mathrm{bb}$ & 32 & 31.5 & 32 & $\mathrm{a}$ & 42 & 104.5 & 104 \\
\hline $\mathrm{bb}$ & 32 & 31.5 & 33 & $\mathrm{a}$ & 42 & 104.5 & 105 \\
\hline $\mathrm{bb}$ & 32 & 31.5 & 34 & $\mathrm{a}$ & 42 & 104.5 & 106 \\
\hline $\mathrm{bb}$ & 32 & 31.5 & 35 & $\mathrm{~b}$ & 42 & 104.5 & 107 \\
\hline aa & 33 & 36.5 & 36 & $\mathrm{a}$ & 43 & 110 & 108 \\
\hline aa & 33 & 36.5 & 37 & $\mathrm{a}$ & 43 & 110 & 109 \\
\hline aa & 34 & 41.5 & 38 & $\mathrm{a}$ & 43 & 110 & 110 \\
\hline aa & 34 & 41.5 & 39 & $\mathrm{~b}$ & 43 & 110 & 111 \\
\hline aa & 34 & 41.5 & 40 & $\mathrm{~b}$ & 43 & 110 & 112 \\
\hline aa & 34 & 41.5 & 41 & $\mathrm{~b}$ & 44 & 113.5 & 113 \\
\hline aa & 34 & 41.5 & 42 & $\mathrm{~b}$ & 44 & 113.5 & 114 \\
\hline aa & 34 & 41.5 & 43 & $\mathrm{a}$ & 45 & 117 & 115 \\
\hline $\mathrm{bb}$ & 34 & 41.5 & 44 & $\mathrm{~b}$ & 45 & 117 & 116 \\
\hline $\mathrm{bb}$ & 34 & 41.5 & 45 & $\mathrm{~b}$ & 45 & 117 & 117 \\
\hline aa & 35 & 50.5 & 46 & $\mathrm{~b}$ & 45 & 117 & 118 \\
\hline aa & 35 & 50.5 & 47 & $\mathrm{~b}$ & 45 & 117 & 119 \\
\hline aa & 35 & 50.5 & 48 & $\mathrm{~b}$ & 46 & 122 & 120 \\
\hline aa & 35 & 50.5 & 49 & $\mathrm{~b}$ & 46 & 122 & 121 \\
\hline $\mathrm{b}$ & 35 & 50.5 & 50 & $\mathrm{~b}$ & 46 & 122 & 122 \\
\hline $\mathrm{bb}$ & 35 & 50.5 & 51 & $\mathrm{~b}$ & 46 & 122 & 123 \\
\hline $\mathrm{bb}$ & 35 & 50.5 & 52 & $\mathrm{~b}$ & 46 & 122 & 124 \\
\hline $\mathrm{bb}$ & 35 & 50.5 & 53 & $\mathrm{a}$ & 47 & 127 & 125 \\
\hline $\mathrm{bb}$ & 35 & 50.5 & 54 & $\mathrm{~b}$ & 47 & 127 & 126 \\
\hline $\mathrm{bb}$ & 35 & 50.5 & 55 & $\mathrm{~b}$ & 47 & 127 & 127 \\
\hline ba & 36 & 61 & 56 & $\mathrm{~b}$ & 47 & 127 & 128 \\
\hline aa & 36 & 61 & 57 & $\mathrm{~b}$ & 47 & 127 & 129 \\
\hline aa & 36 & 61 & 58 & $\mathrm{a}$ & 48 & 132 & 130 \\
\hline aa & 36 & 61 & 59 & $\mathrm{~b}$ & 48 & 132 & 131 \\
\hline aa & 36 & 61 & 60 & $\mathrm{~b}$ & 48 & 132 & 132 \\
\hline $\mathrm{ab}$ & 36 & 61 & 61 & $\mathrm{~b}$ & 48 & 132 & 133 \\
\hline $\mathrm{bb}$ & 36 & 61 & 62 & $\mathrm{~b}$ & 48 & 132 & 134 \\
\hline $\mathrm{bb}$ & 36 & 61 & 63 & $\mathrm{a}$ & 49 & 137 & 135 \\
\hline $\mathrm{bb}$ & 36 & 61 & 64 & $\mathrm{a}$ & 49 & 137 & 136 \\
\hline $\mathrm{bb}$ & 36 & 61 & 65 & $\mathrm{~b}$ & 49 & 137 & 137 \\
\hline $\mathrm{bb}$ & 36 & 61 & 66 & $\mathrm{~b}$ & 49 & 137 & 138 \\
\hline aa & 37 & 69 & 67 & $\mathrm{~b}$ & 49 & 137 & 139 \\
\hline aa & 37 & 69 & 68 & $\mathrm{a}$ & 50 & 141 & 140 \\
\hline $\mathrm{bb}$ & 37 & 69 & 69 & $\mathrm{~b}$ & 50 & 141 & 141 \\
\hline $\mathrm{bb}$ & 37 & 69 & 70 & $\mathrm{~b}$ & 50 & 141 & 142 \\
\hline
\end{tabular}


Based on table 5of the values of Wilcoxon test (Mann - Whitney U-test), $\mathrm{U}_{0}=-3,7230351$ critical values $\mathrm{u}_{\alpha}$ : for $\mathrm{p}<0.05=1.96$, for $\mathrm{p}<0,01=2,58$ at the significance level was calculated.

Using statistical methods and the values, we confirmed H1 hypothesis $\left|\mathrm{U}_{0}\right|>\mathrm{U}_{\alpha}$

\subsection{Student'a Soft-Skills a Stress at School}

Analysing and detecting stressful situations and stress triggering in pupils in school conditions requires the elaboration of possible proposals to eliminate stress factors that negatively affect pupils' performance in achieving success as well as educational behaviours (Sadeghi and Sa'adatpourvahid, 2016). In the current pedagogical discourse, the concept of soft skills, which needs to be developed and promoted in school, comes to the attention. The teacher's job is to recognize and work with pupils’ stressors (Schmidt, Klusmann, Lüdtke, Möller et al., 2017).

Dealing with stress is in literature on psychology described called coping. This term means both intra-psychic and intentional effort to manage, tolerate, and reduce internal and external human requirements, comment (Shankar and Park, 2016). These are extremely demanding requirements, which burden and exceed the resources available to a person. There are several classifications and categorizations of coping behaviour and coping strategies (Shatkin, Diamond, Zhao, Chodaczech et al., 2017). Based on multiple classification types of coping strategies and their orientation, they have agreed on problem solving, emotion management, and escape responses, escape, eviction, use of soothing substances, denial of the situation, and similar. This type of reaction, compared to the previous two, which are very effective, is rarely adaptable. Coping strategies include religion, mental disconnection, acceptance, searching for instrumental, social or emotional support, behavioural shutdown, humour, alcohol and drug use, problem solving planning, active coping, coping suppression, attention, backsliding, self-confrontation, confrontational dealing with stress, blaming others, finding positive aspects of the process, taking personal responsibility for dealing with the situation, self-control, trying to avoid and escaping stress, resignation, monitoring (tendency to search for threats) and others. Coping strategies represent certain behaviours in various stressful situations. Stress reduction resources are addictive, transitive, relatively consistent patterns of management at the behavioural, cognitive or experience levels that individual uses when dealing with internal or external stressors. The repertoire of ways to eliminate stress effectively includes time management, social support, appropriate eating habits, relaxation (e.g. yoga, Macháček's relaxation-activation method, Schultz's autogenous training, Jacobson's progressive relaxation, meditation, biofeedback, massage, wellness, lightning relaxation techniques), say (Singh, 2016), art and music therapy, dance and motion therapy, breathing exercises, positive thoughts and others.

In the context of dealing with stressful situations and stress, we emphasize the ability of the learner to self-regulate, which is understood as the roof concept of self-control representing the ability of an individual to modify the behaviour and adapt it to certain requirements. Self-control can be explained as the effort the pupil spends in controlling their thinking, behaviour, feeling and doing so in accordance with social norms, cultures, ideals, or personal goals. A person who wants to cope with a stressful situation has to master the control of ideas, emotions and block the excitement. It is the regulation of emotions, impulses and behaviour that are the main areas of self-control. The suppression or complete blocking of an experienced tendency to behave with aggressive individuals corresponds to understanding the concept of self-control which is defined in the present psychology as the ability of an individual to overcome or abolish inappropriate behavioural tendencies and withdraw from their realization. It is activated in situations where there is an internal conflict between behavioural tendencies originating from the inside or caused by actual stimulation 
and distant goals, environmental requirements (Slavich, 2016). According to (Sonnentag, 2009) of aggression the self-control should be suppressing the tendency to hurt another person. Support, development and change of soft skills, such as empathy, ability to communicate and teamwork, self-discipline and ability to enroll in school conditions require a planned and long-term activity (Sotardi, 2016). Ability to self-identify, self-control in the interaction of relationships and the environment represents a lifelong journey of personality development. The source of acquiring the first skills to self-recovering one's identity is family. A continuing institution in this direction is school. As we cannot provide "perfect" conditions for socio-emotional development to all parents and families, teachers are also different in socio-emotional competence. Since the school is a professional institution for teachers, a great number of programs, training for the development and maintenance of the pupil's social competencies are being prepared, inform (Sticke and Scott, 2016) and (Tumer and Muholland, 2017). Based on research, stress is a part of the life of individuals (teachers and pupils) in teaching and the learning environment add (Wilkes, Kydd, Sagar and Broadbent, 2017). Authors (Yusofov, Nicoloro, Grey, Moyer et al., 2019) believe that developing soft skills of pupils is a natural prevention to tackle stressful situations. In order to strengthen the soft skills of pupils, it is necessary to support and focus the attention of the teachers themselves.

\section{FUTURE RESEARCH DIRECTIONS}

Another potential future research could be to identify the causes of stress or burnout in teachers. The aim would be to identify these negative factors and try to eliminate them. This could outline possible solutions to suppress or completely prevent the causes of stress in educational institutions. Changes in social life such as aggression, violence, bullying, etc. are very common today. So who is responsible for the causes of excessive stress and negative behaviour in children or adolescents? This may also outline further possible research. However, culture and morality play an important role in suppressing congenital aggression. Researchers on which this research would be carried out should be not only from the Czech and Slovak Republics, but also from other European countries.

\section{CONCLUSION}

The given study presents theoretical analysis of stress, stressors of high school students and the consequent empirical investigation. The objective was to analyse the most frequent reasons or starters of high school student's stress from the point of view of teachers. By comparing statements of teachers, we have processed sequence of most frequently mentioned stressors of students. We have focused on searching for mutual dependence on stress and socio-pathological phenomena and verification of stated hypothesis. Making diagnose and evaluation of stress of student requires application of teacher's competences in multispectral influence. After diagnosis and consequent evaluation, the pedagogical reality requires teacher to work with students in order to eliminate and manage student's potential and real stress.

Ability of self-knowledge, self-control in interaction of relationships and environment represents lifelong journey of personality development. As well as physical, human and social capital can significantly contribute to increased productivity of individuals, groups and organizations. Family is the source where we acquire first skills in order to form the own identity. The school continues in this influence. As well as we cannot ensure ,perfect “conditions for social-emotional development for all parents and families, also teachers have different level of social-emotional competences. Since school is the professional institution, in last year's there were prepared many programmes, trainings for development and keeping of social competences of student for teachers. The GED study (Generalized Educational Development) made by Hackman in the1990's in the USA con- 
firmed that graduates of GED program missed psychical dispositions gained by high school students in the process of regular education. The GED program served as a test in order to get certificate on maturity exam also to easing and undisciplined students on the basis of their success in test. According to the program they were to the large extent ,speculators missing ability to think systematically, to bear tasks, to adapt on the environment and to cope with stress.

Time management is an integral part of prevention of stress and stress situations, emotional control, aggressive motives or temperament. An important role in the prevention of academic stressors is the open, cultivated communication between pupils and pupils and teachers involved in creating a social climate and a favourable atmosphere. With respect to trends and developments in the area of information and communication technologies, mobile applications focusing on relaxation, sporting activities, planning and organizing time and communicating with friends support the management of stressful situations. Mobile Applications Pacific offers cognitive behavioural therapies, meditation, relaxation exercises and breathing to relieve anxiety and stress. It contains more than 25 sound exercises including breathing, relaxing muscles or tuning for positive thinking. The Calmit application, with the subtitle Meditate, offers users primarily meditation exercises, such as sleeping stories, the most common fairy tales for adults to reassure Google Calendar, Trello or Any. Do are application-oriented programming and time management dedicated to managing, performing tasks and responsibilities. Endomondo, Runtastic, Diet applications motivate users to use GPS to create route maps, track distance, speed, average and maximum pace and speed including calories burned. Communication applications with friends as like Messenger, Viber and Skype support day-to-day interpersonal communication.

Building upon above mentioned researches the stress is part of life of individuals (teachers and students) in school environment. The necessary social but also professional condition is to teach students to work with stress factors and to develop their competences and skills in order to deal with difficult situations. Contributors believe that the development of stressful situations, misunderstandings and conflicts often found in non-homogeneous groups and social communities can be avoided in particular by developing soft skills for pupils and students through open communication, regular planning and timing with support for movement, relaxation and meditation activities. In order to strengthen soft skills for pupils and students, it is necessary to pay attention to all participants of the academic environment, to harmonize interpersonal relationships, to sophisticate culture, trust, coordination and motivation in a functional educational process.

\section{ACKNOWLEDGEMENTS}

The scientific contribution is the output of the project: "Strategies to Support Pupil Adherence to Rules in the Educational Environment". Project no. 005DTI-4/2018.

\section{REFERENCES}

Berg, J. K.., \& Cornell, D. (2016). Authoritative school climate, aggression toward teachers, and teacher distress in middle school. In School Psychology Quarterly, 31(1), pp. 122-139.

Blašková, M., Blaško, R., Figurska, I., \& Sokol, A. (2015). Motivation and Development of the University Teachers' Motivational Competence. In Proceeded - Social and Behavioural Sciences, 182, pp. 116-126.

Braun, A. C., \& Carlotto, M. S. (2014). Burnout syndrome: Comparative study between teacher of special education and regular education. In Psicologia Escolare Educational, 18 (1), pp. 125-133.

Cefai, C., \& Camilleri, L. (2015). A Healthy Start: Promoting mental health and wellbeing in the early primary school years. In Emotional and Behaviour Difficulties, 20 (2), pp. 133-152. 
Cordella, M., \& Poiani, A. (2014). Behavioural oncology: Psychological, communicative and social dimensions. In Behavioural Oncology: Psychological, Communicative, and Social Dimensions, pp. 1-802.

da Silva, N. R., Bolsoni Silva, A. T., Rodrigues, O. M. P. R., Capellini, \& V. L. M. F. (2015). The work of special education teachers, burnout indicators and behaviour of students: Correlations and predictions. In Revista Brasileira de Educacao Especial, 21 (3), pp. 363-376.

Davies, D. R., Olson, D., Meyer, D. L., Renner, K. J., Forster, \& G. L. (2016). Mild traumatic brain injury with social defeat stress alters anxiety, Contextual fear extinction, and limbic monoamines in adult rats. In Frontiers in Behavioural Neuroscience, 10 (71).

Denscombe, M. (2000). Social conditions for stress. In British Educational Research Journal, 26 (3), pp. 259-374.

Eldor, L. (2018). Public service sector: The compassionate workplace - The effect of compassion and stress on employee engagement, burnout, and performance. In Journal of Public Administration Research and Theory, 28 (1), pp. 86-103.

Eva, A. L., \& Thayer, N. M. (2017). The Mindful Teacher: Translating Research into Daily Well-Being. In Clearing House: A Journal of Educational Strategies, Issues and Ideas, 90 (1), pp. 18-25.

Fisher, M. H. (2011). Factors influencing stress, burnout, and retention of secondary teachers. In Current Issues in Education, 14 (1), pp. 1-31.

Folkman, S., \& Lazarus, R. S. (1980). An Analysis of Coping in a Middle-Aged Community Sample. In Journal of Health and Social Behaviour, 21 (3), pp. 219-39.

Gabrhelová, G. (2017). Pracovný stres učitel'a v edukačnej realite. 1. ed. Brno: Tribun, 2011. ISBN 978-80-263-1314-4.

Gailliot, M. T., \& Baumeister, R. J. (2007). The Physiology of Willpower: Linking to blood glucose self-control. In Personality and Social Psychology Review, 11, pp. 303-327.

Ganzel, B. L., Morris, P. A., \& Wethington, E. (2010). All stasis and the Human Brain: Integrating Models of Stress from the Social and Life Sciences. In Psychological Review, 117 (1), pp. 134-174.

Gouda, S., Luong, M. T., Schmidt, S., \& Bauer, J. (2016). Students and teachers benefit from mindfulness-based stress reduction in a school-embedded pilot study. In Frontiers in Psychology, 7(APR), pp. 590.

Grise-Owens, E., Miller, J. J., Escobar Ratliff, L., \& George, N. (2018). Teaching Note-Teaching Self-Care and Wellness as a Professional Practice Skill: A Curricular Case Example. In Journal of Social Work Education, 54 (1), pp. 180-186.

Gustems Carnicer, J., Calderón, C., \& Calderón Garrido, D. (2019). Stress, coping strategies and academic achievement in teacher education students. In European Journal of Teacher Education, 42 (3), pp. 375-390.

Havelka, M., Kropáč, J., Serafín, Č., Chráska, M., \& Částková, P. (2015). The choice of educational and professional path of basic school pupils as a component of the realisation of the technical education. In Turkish Online Journal of Educational Technology, pp. 544-550.

Hong, J. Y. (2012). Why do some beginning teachers leave the school, and others stay? Understanding teacher resilience through psychological lenses. In Teachers and Teaching: Theory and Practice, 18 (4), pp. 417-440.

Hutkemri, Ahmad, N. A., \& Jelas, Z. M. (2017). Adolescent learning support: Relationship with burnout and achievement. In Advanced Science Letters, 23 (3), pp. 2137-2140.

Inmaculada, C. L., \& Glòria, R. (2016). The importance of self-regulation and empathy in teacher training. In Movimento, 22 (1), pp.157-172.

Kalyva, E. (2013). Stress in Greek primary schoolteachers working under conditions of financial crisis. In Europe's Journal of Psychology, 9 (1), pp. 104-112. 
Kandlhofer, M., \& Steinbauer, G. (2016). Evaluating the impact of educational robotics on pupils' technical- and social-skills and science related attitudes. In Robotics and Autonomous Systems, 75 , pp. 679-685.

Kopp, H., Kuhlmann, T. M., \& Golpelwar, M. K. (2016). Global call centre employees in India: Work and life between globalization and tradition. In Global Call Centre Employees in India: Work and Life between Globalization and Tradition, pp. 1-214.

Lai, F. T. T., \& Kwan, J. L. Y. (2017). Socioeconomic influence on adolescent problematic Internet use through school-related psychosocial factors and pattern of Internet use. In Computers in Human Behaviour, 68, pp. 121-136.

Lavner, J. A., \& Bradbury, T. N. (2017). Protecting relationships from stress. In Current Opinion in Psychology, 13, pp. 11-14.

Leach, P. K., Nygaard, R. M., Chipman, J. G., Brunsvold, M. E., \& Marek, A. P. (2019). Impostor Phenomenon and Burnout in General Surgeons and General Surgery Residents. In Journal of Surgical Education, 76 (1), pp. 99-106.

Lin, S. H., \& Huang, Y. Ch. (2014). Life Stress and Academic Burnout. Active Learning in Higher Education, 15 (1), pp. 77-90.

Meriläinen, M. (2014). Factors affecting study-related burnout among Finnish university students: teaching-learning environment, achievement motivation and the meaning of life. In Quality in Higher Education, 20 (3), pp. 309-329.

Özberk, K., Dağli, G., Altinay, F., \& Altinay, Z. (2017). Job burnout among teachers in secondary education. In International Journal of Economic Perspectives, 11 (1), pp. 720-729.

Prilleltensky, I., Neff, M., \& Bessell, A. (2016). Teacher Stress: What It Is, Why It's Important, How It Can Be Alleviated? In Theory into Practice, 55 (2), pp. 104-111.

Randall, A. K., \& Bodenmann, G. (2017). Stress and its associations with relationship satisfaction. In Current Opinion in Psychology, 13, pp. 96-106.

Reichl, C., Wach, F. S., Spinath, F. M., Brünken, R., \& Karbach, J. (2014). Burnout risk among first-year teacher students: The roles of personality and motivation. In Journal of Vocational Behaviour, 85 (1), pp. 85-92.

Roslan, S., Sharifah, M. N., \& Thirumalai, V. N. (2012). The burnout phenomenon: Changes in psychosocial profiles of secondary school teachers. In Pertanika Journal of Social Science and Humanities, 20, pp. 157-174.

Sadeghi, K., \& Sa'adatpourvahid, M. (2016). EFL Teachers' Stress and Job Satisfaction: What Contribution Can Teacher Education Make? In Iranian Journal of Language Teaching Research, 4 (3), pp. 75-96.

Schmidt, J., Klusmann, U., Lüdtke, O., Möller, J., \& Kunter, M. (2017). What makes good and bad days for beginning teachers? A diary study on daily uplifts and hassles. In Contemporary Educational Psychology, 48, pp. 85-97.

Shankar, N. L., \& Park, C. L. (2016). Effects of Stress on Students' Physical and Mental Health and Academic Success. In International Journal of School \& Educational Psychology, 4 (1), pp. 5-9.

Shatkin, J. P., Diamond, U., Zhao, Y., Chodaczek, M., \& Bruzzese, J. M. (2017). Effects of a Risk and Resilience Course on Stress, Coping Skills, and Cognitive Strategies in College Students. In Teaching of Psychology, 43 (3), pp. 204-210.

Singh, R. (2016). Stress among School-Going Adolescents in Relation to Psychological Hardiness. In Journal on Educational Psychology, 9 (4), pp. 8-15.

Slavich, G. M. (2016). Life Stress and Health: A Review of Conceptual Issues and Recent Findings. In Teaching of Psychology, 43 (4), pp. 346-355.

Sonnentag, S. (2009). Current Perspectives on Job-stress. Recovery. In Research in Occupational Stress and Well-being, 7, pp. 205-247. 
Sotardi, V. A. (2016). Understanding Student Stress and Coping in Elementary School: A Mixed-Method, Longitudinal Study. In Psychology in the Schools, 53 (7), pp. 705-721.

Stickle, F. E., \& Scott, K. (2016). Leadership and Occupational Stress. In Education, 137 (1), pp. 27-38.

Turner, J., \& Mulholland, G. (2017). Enterprise education: Towards a framework for e ffective engagement with the learners of today. In Journal of Management Development, 36 (6), pp. 801-816.

Wilkes, C., Kydd, R., Sagar, M., \& Broadbent, E. (2017). Upright posture improves affect and fatigue in people with depressive symptoms. Upright posture improves affect and fatigue in people with depressive symptoms. In Journal of Behaviour Therapy and Experimental Psychiatry, 54, pp. 143-149.

Yusufov, M., Nicoloro Santa Barbara, J., Grey, N. E., Moyer, A., \& Lobel, M. (2019). Meta-analytic evaluation of stress reduction interventions for undergraduate and graduate students. International Journal of Stress Management, 26 (2), pp. 132-145. 